\title{
Prevalence and determinants of low protein intake in very old adults: insights from the Newcastle 85+ Study
}

\author{
Nuno Mendonça $a^{1,2,3}\left(\right.$ Antoneta Granic $^{2,4,5} \cdot$ John C. Mathers ${ }^{2,3,6} \cdot$ Tom R. Hill ${ }^{1,2,3}$ • \\ Mario Siervo $^{2,3,6}$ • Ashley J. Adamson ${ }^{2,3,7}$ • Carol Jagger ${ }^{2,7}$
}

Received: 12 June 2017 / Accepted: 17 September 2017 / Published online: 25 September 2017

(C) The Author(s) 2017. This article is an open access publication

\begin{abstract}
Purpose The very old (aged $\geq 85$ years), fastest growing age group in most western societies, are at especially high risk of muscle mass and strength loss. The amount, sources and timing of protein intake may play important roles in the aetiology and management of sarcopenia. This study investigated the prevalence and determinants of low protein intake in 722 very old adults participating in the Newcastle $85+$ Study.

Methods Protein intake was estimated with $2 \times 24-\mathrm{h}$ multiple pass recalls (24 h-MPR) and contribution (\%) of food groups to protein intake was calculated. Low protein intake
\end{abstract}

Electronic supplementary material The online version of this article (doi:10.1007/s00394-017-1537-5) contains supplementary material, which is available to authorized users.

Nuno Mendonça

n.m.p.mendonca@newcastle.ac.uk

1 School of Agriculture Food and Rural Development, Newcastle University, Newcastle upon Tyne NE1 7RU, UK

2 Newcastle University Institute for Ageing, Newcastle University, Newcastle upon Tyne NE2 4AX, UK

3 Human Nutrition Research Centre, Newcastle University, Newcastle upon Tyne NE2 4HH, UK

4 Institute of Neuroscience, Newcastle University, Newcastle upon Tyne NE2 4HH, UK

5 NIHR Newcastle Biomedical Research Centre in Ageing and Chronic Disease, Newcastle University and Newcastle upon Tyne NHS Foundation Trust, Newcastle upon Tyne NE4 5PL, UK

6 Institute of Cellular Medicine, Newcastle University, Newcastle upon Tyne NE4 5PL, UK

7 Institute of Health and Society, Newcastle University, Newcastle upon Tyne NE4 5PL, UK was defined as intake $<0.8 \mathrm{~g}$ of protein per adjusted body weight per day. A backward stepwise multivariate linear regression model was used to explore socioeconomic, health and lifestyle predictors of protein intake.

Results Twenty-eight percent $(n=199)$ of the communityliving very old in the Newcastle $85+$ Study had low protein intake. Low protein intake was less likely when participants had a higher percent contribution of meat and meat products to total protein intake (OR $0.97,95 \%$ CI $0.95,1.00$ ) but more likely with a higher percent contribution of cereal and cereal products and non-alcoholic beverages. Morning eating occasions contributed more to total protein intake in the low than in the adequate protein intake group $(p<0.001)$. Being a woman $(p<0.001)$, having higher energy intake $(p<0.001)$ and higher tooth count $(p=0.047)$ was associated with higher protein intake in adjusted models.

Conclusion This study provides novel evidence on the prevalence of low protein intake, diurnal protein intake patterns and food group contributors to protein intake in the very old.

Keywords Protein - Malnutrition - Aged, 80 and over . Very old $\cdot$ Newcastle $85+$
Abbreviations
CCP Cereals and cereal products
MMP Meat and meat products
RDA Recommended dietary allowance

\section{Introduction}

The very old (aged $\geq 85$ years), the fastest growing age group in most western societies, are at especially high risk of malnutrition, sarcopenia and loss of muscle strength. In 
the UK, $18 \%$ of the very old are at medium or high risk of malnutrition (measured with the Malnutrition Universal Screening Tool) [1] and although hospitalised older adults are at relatively higher risk, most very old malnourished people reside at home $[2,3]$. Essential amino acids, especially leucine, directly stimulate myofibrillar muscle synthesis through the mTOR pathway and an adequate protein intake is critical to replace losses from catabolic processes [4]. Albeit multifactorial, protein intake, its sources and timing of intake may play important roles in the aetiology and management of ageing-related muscle and strength loss (sarcopenia). In the Dutch National Food Consumption Survey (DNFCS), up to $10 \%$ of community-living older adults ( $\geq 65$ years) did not meet the estimated average requirement (EAR) of $0.7 \mathrm{~g}$ of protein per $\mathrm{kg}$ of body weight per day (g/kg BW/day) [5] and close to $10 \%$ of women $>71$ years had protein intakes below the EAR in the National Health and Nutrition Examination Survey (NHANES) 2003-2004 [6]. Protein intakes below the current recommended dietary allowance (RDA) of $0.8 \mathrm{~g} / \mathrm{kg}$ BW/day have been linked to adverse health outcomes, including physical impairment, muscle loss, dementia and mortality [7-9]. On average, older adults have lower protein intakes than their younger counterparts because of loss of independence, changes in oral health and taste perception and, higher incidence of chronic diseases and disabilities [10]. Disease-related catabolism and inflammation may also increase protein requirements $[11,12]$ which can be coupled with decreased muscle protein responsiveness to protein intake (anabolic resistance) [11].

Research is lacking in understanding of the prevalence and determinants of low protein intake, principal protein food sources, and eating occasions in very old adults. Therefore, utilizing dietary data from the Newcastle $85+$ Study we aimed to describe (a) the prevalence and (b) determinants and factors associated with low and adequate protein intake in the very old.

\section{Methods}

\section{Newcastle 85+ Study}

Details of the Newcastle 85+ Study can be found elsewhere [13-15]. Briefly, this longitudinal population-based study approached all people turning 85 in 2006 (born in 1921) in North East England. The recruited cohort was sociodemographically representative of the general UK population [13]. At baseline (2006/2007), multidimensional health assessment and complete general practice (GP) medical records data were available for 845 participants [14], of whom 722 were living in the community, had complete dietary intake data (without protocol violation), and body weight and height measurements.

\section{Dietary assessment and food group coding}

Dietary intake was assessed by $24 \mathrm{~h}$ Multiple Pass Recall (24 h-MPR) on two non-consecutive occasions by trained research nurses and portion sizes were estimated using the "Photographic Atlas of Food Portion Sizes" [16, 17]. Energy and protein intakes were estimated using McCance and Widdowson's sixth edition food composition tables [18]. Individual foods were coded and allocated to 15 first level food groups: cereals and cereal products (CCP), milk and milk products, eggs and egg dishes, oils and fat spreads, meat and meat products (MMP), fish and fish dishes, vegetables, potatoes, savoury snacks, nuts and seeds, fruit, sugar, preserves and confectionery, non-alcoholic beverages, alcoholic beverages and miscellaneous. One approach to estimate protein inadequacy and base recommendations for protein RDA of $0.8 \mathrm{~g} / \mathrm{kg} \mathrm{BW} /$ day is to use adjusted body weight (aBW) defined as the nearest (ideal) body weight that would put an older adult aged $\geq 71$ years into a healthy body mass index (BMI) of $22-27 \mathrm{~kg} / \mathrm{m}^{2}[19,20]$. Low protein intake was defined as an intake $<0.8 \mathrm{~g} / \mathrm{kg}$ of unadjusted bodyweight per day $(\mathrm{g} / \mathrm{kg}$ aBW/day) and adequate protein intake as $\geq 0.8 \mathrm{~g} / \mathrm{kg}$ aBW/day. Eating occasions were categorised into 5:30-8:29, 8:30-11:29, 11:30-14:29, 14:30-17:29, 17:30-20:29, 20:30-23:29 and 23:30-5:29. Protein intake distribution was calculated as the coefficient of variation (CV) (standard deviation/total protein intake) between eating occasions (occasions of food intake where energy intake was zero were not included). Higher CVs reflect more skewed protein intake across the day. We also calculated the number of eating occasions that had 20 and $30 \mathrm{~g}$ of protein as well as how many participants had at least one of those eating occasions. Misreporting was taken into consideration but not included in the analyses. Briefly, under-reporters and over-reporters were defined as having an EI:BMRest below 1.05 and over 2.0, respectively [21].

\section{Socioeconomic, lifestyle and health factors}

Body weight was adjusted to reflect a healthy body mass index (BMI) in older adults of $22-27 \mathrm{~kg} / \mathrm{m}^{2}$ and calculated as described in Berner et al. [20]. Briefly, if necessary, the actual body weight was adjusted to the nearest (ideal) weight that would put an individual into an age-appropriate ( $\geq 71$ years) healthy BMI range associated with a decreased risk of mortality. Fat mass and fat-free mass were assessed using a Tanita-305 body-fat analyser (Tanita Corp., Tokyo, Japan). Participants were categorised into the National Statistics Socio-Economic Classification (NS-SEC) threeclass scheme [22] based on past main occupation; and, for physical activity, into those with low (scores $0-1$ ), medium (scores 2-6) and high (scores 7-18) based on a purpose designed and validated physical activity questionnaire [23]. 
Meal provision included meals provided by the social services, voluntary services or other private help in the previous 4 weeks, and luncheon club attendance was defined as at least one visit in the previous 4 weeks. Biomarkers frequently used in malnutrition assessments and included in these analyses are: serum albumin (measured by an automated version of the bromocresol green method), total cholesterol (determined by the cholesterol oxidase/peroxidase method with a Beckman Coulter AU2700 analyser), and high sensitivity C-reactive protein (hs-CRP) (measured with a Dade Behring Cardiophase hsCRP immunoassay). Disease count was created by scoring 17 chronic diseases as either present or absent [24]; a participant with an estimated glomerular filtration rate $<30 \mathrm{ml} / \mathrm{min} / 1.73 \mathrm{~m}^{2}$ was defined as renally impaired; global cognition was assessed with the standardised mini-mental state examination (SMMSE; 0-30 points, $<26$ indicating cognitive impairment); depression was assessed by the 15-item Geriatric Depression Scale (GDS; $\leq 8$ points indicating severe depression); and oral health included swallowing problems (dry mouth and difficulty swallowing for other reasons) and tooth count.

\section{Statistical analysis}

Statistical analysis was conducted using the IBM statistical tool SPSS v22.0. For continuous variables, normality was tested using the Shapiro-Wilk test and confirmed with Q-Q plots; normally distributed data are presented as means and standard deviations (SD), and non-Gaussian distributed variables as medians and interquartile ranges (IQR). Categorical data are presented as percentages (with corresponding sample size). Differences between the low protein intake $(<0.8 \mathrm{~g} / \mathrm{kg} \mathrm{aBW} /$ day $)$ and adequate protein intake ( $\geq 0.8 \mathrm{~g} / \mathrm{kg}$ aBW/day) strata were assessed with two sample $t$ test and Mann-Whitney $U$ test for continuous normally and non-normally distributed variables, respectively, and Chi-squared test $\left(\chi^{2}\right)$ for categorical variables. Sex (men/women), past occupation (routine and manual/intermediate/higher managerial and administrative and professional occupations), education $(<9,10-11$ and $\geq 12$ years of full-time education), living alone (no/ yes), meal provision (no/yes), luncheon club attendance (no/yes), smoker (no/yes), alcohol drinker (no/yes), physical activity (low, medium, high), diet changed past year (no/yes), energy intake, serum albumin, total cholesterol, hs-CRP, disease count (0-1, 2 and $\geq 3$ diseases), renal impairment (yes/no), number of medications, SMMSE, depression (absent, mild, severe), tooth count, swallowing problems (no/yes), self-rated health (fair or poor/good, very good or excellent), able to cook a hot meal and able to go shopping for groceries (no difficulty, able to but with help or an aid, and unable to do this by himself/herself) were entered into a backward stepwise multivariate linear regression model. $p<0.05$ was considered statistically significant unless otherwise mentioned.

\section{Results}

\section{Participants' characteristics by low or high protein intake}

The median protein intake of the community-living very old in the Newcastle $85+$ Study was $0.97(0.77-1.24) \mathrm{g} / \mathrm{kg}$ aBW/d and 0.99 (0.77-1.24) g/kg unadjusted BW/d. Twentyeight percent $(n=199)$ of the community-living very old in the Newcastle $85+$ Study had a low protein intake $(<0.8 \mathrm{~g}$ of protein per $\mathrm{kg}$ of aBW) (Table 1 and Supplemental Fig. 1), or 10 fewer people $(n=189)$ if the calculations used unadjusted rather than adjusted body weight. Fifty-four percent $(n=390)$ had protein intakes $<1.0 \mathrm{~g} / \mathrm{kg} \mathrm{aBW} /$ day and $75 \%(n=539)<1.2 \mathrm{~g} / \mathrm{kg}$ aBW/day (Supplemental Fig. 1$)$. Participants with a higher BMI, more fat mass, less energy intake, more even protein distribution throughout the day and lower tooth count had low protein intake (unadjusted models). Albumin and hs-CRP concentrations tended to be lower $(p=0.059)$ and higher $(p=0.056)$, respectively, in the low compared with the adequate protein intake group ( $\geq 0.8 \mathrm{~g} / \mathrm{kg} \mathrm{aBW} /$ day) (Table 1$)$.

\section{Contribution of food groups to protein intake}

Those with adequate protein intake consumed more of almost every food group (weight in g). MMP contributed 6\% more to protein intake $(p<0.001)$ while CCP $(p=0.009)$ and most other food groups contributed less to protein intake in the adequate protein intake group $(\geq 0.8 \mathrm{~g} / \mathrm{kg}$ $\mathrm{aBW} /$ day $)$ than in the low protein group $(<0.8 \mathrm{~g} / \mathrm{kg} \mathrm{aBW} /$ day) (Table 2). Higher consumption (but also higher protein intake) of CCP, MMP and milk and milk products was associated with a lower likelihood of having low total protein intake ( $<0.8 \mathrm{~g} / \mathrm{kg}$ aBW/day) (Supplemental Table 1). However, when calculated as the percent contribution of food groups to total protein intake, only higher percent contribution of MMP to total protein intake was associated with reduced risk of low protein intake (OR 0.97, 95\% CI 0.95, 1.00). On the other hand, higher percent contribution of $\mathrm{CCP}$ and non-alcoholic beverages to protein intake were associated with increased ORs of low protein intake. The models were adjusted for sex, energy intake, BMI and the other top protein-contributing food groups (MMP, CCP, milk and milk products and non-alcoholic beverages but not fish and fish 
Table 1 Health and sociodemographic characteristics of the Newcastle 85+ Study participants with low and adequate protein intakes

\begin{tabular}{|c|c|c|c|}
\hline & Low $\operatorname{protein}^{\mathrm{a}}(n=199)$ & 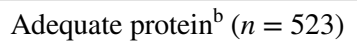 & $p$ value* \\
\hline Women $(\%, n)$ & $67.3(134)$ & $57.2(299)$ & 0.013 \\
\hline Education $(\geq 12 \mathrm{y})(\%, n)$ & $10.1(20)$ & $13.5(70)$ & 0.459 \\
\hline Past occupation (routine and manual) $(\%, n)$ & $52.4(100)$ & 49.5 (249) & 0.625 \\
\hline Living alone $(\%, n)$ & $59.3(118)$ & $57.3(299)$ & 0.624 \\
\hline Meal provision $(\%, n)$ & $4.6(9)$ & $7.2(36)$ & 0.209 \\
\hline Luncheon club $(\%, n)$ & $7.5(15)$ & $7.0(37)$ & 0.818 \\
\hline Unable to prepare hot meal $(\%, n)$ & $9.5(19)$ & $9.6(50)$ & 0.692 \\
\hline Unable to go shopping alone $(\%, n)$ & $36.2(72)$ & $34.4(180)$ & 0.568 \\
\hline \multicolumn{4}{|l|}{ Anthropometry } \\
\hline BMI $\left(\mathrm{kg} / \mathrm{m}^{2}\right)($ mean, $\mathrm{SD})$ & $25.9(4.7)$ & $24.0(4.1)$ & $<0.001$ \\
\hline Adjusted body weight (kg) & $65.7(60.2-69.9)$ & $62.4(56.6-68.8)$ & 0.001 \\
\hline Weight loss $(\geq 5 \%$ in $3 \mathrm{y})(\%, n)$ & $47.0(47)$ & $37.7(112)$ & 0.101 \\
\hline Fat mass $(\mathrm{kg})($ mean, SD) & $21.7(8.1)$ & $17.9(7.3)$ & $<0.001$ \\
\hline Fat-free mass (kg) & $43.7(39.2-52.2)$ & $43.2(37.5-51.4)$ & 0.136 \\
\hline \multicolumn{4}{|l|}{ Lifestyle } \\
\hline Physical activity (high) $(\%, n)$ & $31.7(63)$ & 39.5 (206) & 0.121 \\
\hline Smokers $(\%, n)$ & $5.6(11)$ & $6.1(32)$ & 0.776 \\
\hline Alcohol drinkers $(\%, n)$ & $71.8(102)$ & $74.1(269)$ & 0.603 \\
\hline \multicolumn{4}{|l|}{ Dietary intake } \\
\hline Diet changed past year $(\%, n)$ & $7.6(15)$ & $6.4(33)$ & 0.564 \\
\hline Total energy (MJ/day) & $5.3(4.2-6.3)$ & $7.4(6.3-8.8)$ & $<0.001$ \\
\hline Carbohydrates (g/day) & $151(119-192)$ & $209(172-253)$ & $<0.001$ \\
\hline Total energy from carbohydrates (\%) & $50.2(45.1-55.9)$ & $47.9(43.3-53.4)$ & $<0.001$ \\
\hline Fat (g/day) & $48(37-64)$ & $72(57-91)$ & $<0.001$ \\
\hline Total energy from fat (\%) & $35.7(29.6-40.7)$ & $35.5(31.2-41.1)$ & 0.084 \\
\hline Total protein (g/day) & $42(37-49)$ & $68(58-82)$ & $<0.001$ \\
\hline Total energy from protein $(\%)$ & $13.0(11.6-16.2)$ & $15.8(13.8-18.2)$ & $<0.001$ \\
\hline Total protein (g/kg aBW/day) & $0.7(0.6-0.7)$ & $1.1(0.9-1.3)$ & $<0.001$ \\
\hline Protein distribution (CV) (mean, SD) & $0.18(0.07)$ & $0.19(0.06)$ & 0.024 \\
\hline \multicolumn{4}{|l|}{ Biochemical } \\
\hline Albumin $(\mathrm{g} / \mathrm{L})$ & $40(38-42)$ & $41(39-42)$ & 0.059 \\
\hline hs-CRP (mg/L) & $2.8(1.4-6.2)$ & $2.4(1.1-5.7)$ & 0.056 \\
\hline Total cholesterol (mmol/L) & $4.8(3.9-5.8)$ & $4.8(4.0-5.7)$ & 0.399 \\
\hline \multicolumn{4}{|l|}{ Health } \\
\hline Chronic disease count $(\geq 3)(\%, n)$ & $45.2(90)$ & $37.7(197)$ & 0.138 \\
\hline Number of medications & $6(4-9)$ & $6(3-8)$ & 0.381 \\
\hline Renal impairment $(\%, n)$ & $27.6(53)$ & $22.1(112)$ & 0.125 \\
\hline Cognitive impairment $($ SMMSE $<26)(\%, n)$ & $21.5(53)$ & $26.6(112)$ & 0.139 \\
\hline Severe depression $(\%, n)$ & $7.1(14)$ & $7.3(37)$ & 0.907 \\
\hline Swallowing problems $(\%, n)$ & $56.3(112)$ & $58.2(304)$ & 0.635 \\
\hline Tooth count (mean, SD) & $5.3(8.0)$ & $6.7(8.5)$ & 0.013 \\
\hline Self-rated health (fair or poor) $(\%, n)$ & $24.9(49)$ & $20.2(105)$ & 0.373 \\
\hline
\end{tabular}

Values are medians and interquartile ranges unless stated otherwise. Meal provision included meals provided by the social services, voluntary services or other private help in the previous 4 weeks. Luncheon club comprises visits also in the previous 4 weeks. Swallowing problems included dry mouth and difficulty swallowing for other reasons. Protein intake distribution was calculated as SD/total protein intake with higher values reflecting more skewness of intakes across time intervals in the day

$a B W$ adjusted body weight $(\mathrm{kg}), B M I$ body mass index, $C V$ coefficient of variation, $h s-C R P$ high sensitivity C-reactive protein, $S M M S E$ standardised mini-mental state examination, $y$ years

*Chi-squared test $\left(\chi^{2}\right)$ was used for categorical variables, independent $t$ test for continuous normally distributed variables and Mann-Whitney $U$ test for no protein intake difference for continuous non-normally distributed variables 
Table 1 (continued)

${ }^{\mathrm{a}}$ A protein intake $<0.8 \mathrm{~g} / \mathrm{kg} \mathrm{aBW} /$ day was considered low

${ }^{\mathrm{b}} \geq 0.8 \mathrm{~g} / \mathrm{kg}$ aBW/day was considered adequate. Body weight was adjusted to the nearest value to reflect a healthy BMI in older adults aged $\geq 71$ years of $22-27 \mathrm{~kg} / \mathrm{m}^{2}$ as described in Berner et al. [20]

Table 2 Consumption (g/day) and contribution of 15 food groups to protein intake (\%) among consumers with low and adequate protein intakes

\begin{tabular}{|c|c|c|c|c|c|c|}
\hline \multirow[t]{2}{*}{ Food groups } & \multicolumn{3}{|c|}{ Consumption weight (g/day) } & \multicolumn{3}{|c|}{ Contribution to protein intake (\%) } \\
\hline & Low protein ${ }^{\mathrm{a}}$ & Adequate protein ${ }^{\mathrm{a}}$ & $p$ value* & Low protein ${ }^{\mathrm{a}}$ & Adequate protein ${ }^{\mathrm{a}}$ & $p$ value* \\
\hline Meat and meat products & $72.5(43.4-110.4)$ & $128.5(82.5-187.3)$ & $<0.001$ & $30.7(19.6-40.5)$ & $37.0(23.8-47.7)$ & $<0.001$ \\
\hline Cereals and cereal products & $145.5(105.3-203.8)$ & $239.5(164.0-334.5)$ & $<0.001$ & $25.4(19.2-32.2)$ & $23.1(17.5-30.0)$ & 0.009 \\
\hline Fish and fish dishes & $45.0(23.8-60.0)$ & $64.0(42.0-103.0)$ & $<0.001$ & $15.6(10.4-21.5)$ & $16.8(10.2-25.8)$ & 0.327 \\
\hline Milk and milk products & $105.8(50.0-195.8)$ & $155.5(75.8-245.6)$ & $<0.001$ & $11.7(6.2-20.6)$ & $10.7(6.4-17.4)$ & 0.196 \\
\hline Eggs and egg dishes & $30.0(25.0-55.0)$ & $30.0(25.0-60.0)$ & 0.108 & $10.4(6.3-16.8)$ & $7.0(4.6-10.7)$ & $<0.001$ \\
\hline Non-alcoholic beverages ${ }^{b}$ & $1100(880-1415)$ & $1265(960-1573)$ & $<0.001$ & $9.5(6.0-12.2)$ & $6.6(4.2-8.9)$ & $<0.001$ \\
\hline Nuts and seeds & $13.8(8.5-18.8)$ & $15.5(6.0-23.5)$ & 0.760 & $5.4(4.6-6.4)$ & $3.6(2.1-5.5)$ & 0.071 \\
\hline Vegetables & $89.0(49.0-134.0)$ & $114.5(65.3-171.0)$ & $<0.001$ & $4.5(2.0-7.3)$ & $3.5(1.8-5.4)$ & 0.002 \\
\hline Potatoes & $84.3(48.5-138.0)$ & $110.5(70.0-160.5)$ & $<0.001$ & $4.0(2.2-6.5)$ & $3.1(2.0-4.9)$ & 0.002 \\
\hline Fruit & $124.5(85.3-197.8)$ & $157.5(84.8-247.3)$ & 0.023 & $2.2(1.2-3.5)$ & $1.5(0.8-2.6)$ & $<0.001$ \\
\hline Savoury snacks & $14.0(8.4-14.0)$ & $14.0(7.0-17.1)$ & 0.887 & $1.7(1.1-2.7)$ & $1.1(0.7-1.5)$ & 0.002 \\
\hline Miscellaneous & $65.0(20.0-150.0)$ & $53.0(22.0-141.0)$ & 0.602 & $1.2(0.3-5.3)$ & $0.7(0.2-2.9)$ & 0.002 \\
\hline Sugar, preserves and confectionery & $16.0(10.0-32.6)$ & $21.3(11.4-39.0)$ & 0.032 & $1.4(0.0-2.0)$ & $0.2(0.0-1.2)$ & 0.448 \\
\hline Alcoholic beverages & $124.0(50.0-445.5)$ & $135.8(53.8-288.5)$ & 0.924 & $0.2(0.0-2.3)$ & $0.2(0.0-0.7)$ & 0.209 \\
\hline Oils and fat spreads & $16.0(9.0-24.0)$ & $18.0(12.0-28.0)$ & 0.005 & $0.1(0.1-0.3)$ & $0.1(0.1-0.3)$ & 0.054 \\
\hline
\end{tabular}

Values are medians and interquartile ranges

$a B W$ adjusted body weight $(\mathrm{kg})$

*Mann-Whitney $U$ test for no difference between low $<0.8 \mathrm{~g} / \mathrm{kg}$ aBW/day) and adequate protein intake ( $\geq 0.8 \mathrm{~g} / \mathrm{kg}$ aBW/day)

${ }^{a}$ Body weight was adjusted to reflect a healthy BMI in older adults of $22-27 \mathrm{~kg} / \mathrm{m}^{2}$

${ }^{\mathrm{b}}$ Includes tea/coffee with added milk

dishes or egg and egg dishes as the percent of consumers was only 35\% and 38\%, respectively) (Supplemental Table 1).

\section{Protein intake by eating occasion}

Ninety-nine percent of participants in the analytic sample $(n=714)$ consumed a meal between $11: 30$ and 14:29 but only $16 \%(n=112)$ consumed one between 23:30 and 5:29 (Fig. 1). Most of the protein intake [ 35\% or $20.4 \mathrm{~g}$ (12.8-30.4)] occurred during the "lunch" period (11:30-14:29) followed by the "dinner" period (17:30-20:29) [ $21 \%$ or $12.0 \mathrm{~g}(4.2-24.3)]$. The two morning eating occasions (5:30-8:29 and 8:30-11:29) combined, contributed to $\sim 22 \%$ or $12.9 \mathrm{~g}(5.5-20.8)$ of the total protein intake. Those with protein intake $\geq 0.8 \mathrm{~g} / \mathrm{kg}$ aBW/day had greater protein intake (g/day) in almost every eating occasion (time category) (Fig. 1 and Supplemental Table 2). However, percent contribution to total protein intake during the early part of the day (5:30-8:29 and 8:30-11:29) was higher in the low than in the adequate protein intake group ( $p=0.002$ and $p=0.004$, respectively) (Table 3).
This finding was confirmed by linear and binary logistic regression models adjusted for health and sociodemographic characteristics $(p<0.001)$ (Supplemental Table 3).

Twenty-one percent and $10 \%$ of the eating occasions had more than 20 and $30 \mathrm{~g}$ of protein, respectively. These eating occasions occurred mostly during the "lunch" (11:30-14:29) and "dinner" period (17:30-20:29) or in between (14:30 and 17:29). For example, half (52\%) of every "lunch" eating occasion but only $4 \%(5: 30-8: 29)$ and $6 \%(8: 30-11: 29)$ of "breakfast" eating occasions had more than $20 \mathrm{~g}$ of protein [25] (Fig. 1). Consumption of at least $20 \mathrm{~g}$ of protein within any one eating occasion was predictive of adequate protein intake after adjustment for sex, energy intake and BMI (OR $0.07,95 \%$ CI $0.04,0.13)$. There were insufficient numbers of participants $(n=15)$ who had both low total protein intakes $(<0.8 \mathrm{~g} / \mathrm{kg}$ aBW/day) and an eating occasion with $\geq 30 \mathrm{~g}$ of protein to replicate the analysis for this cutoff. 


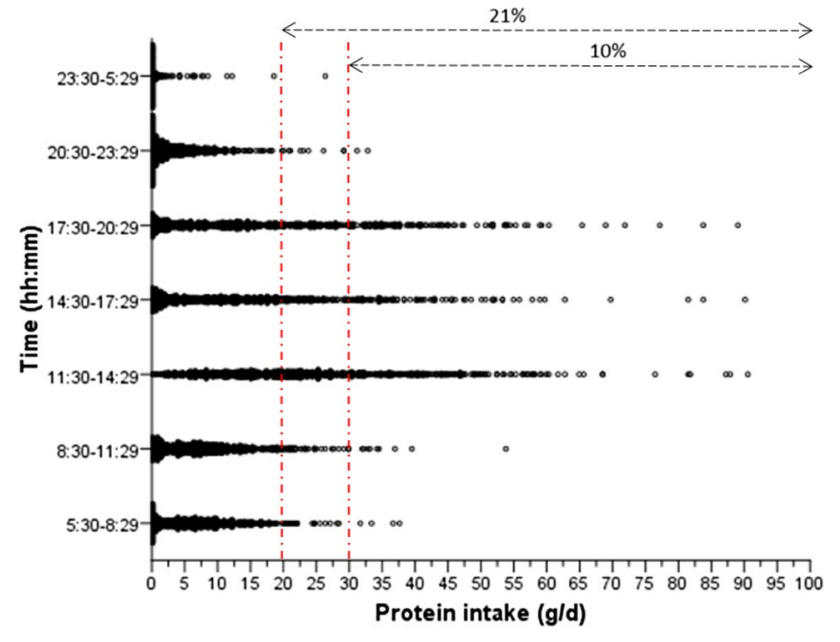

Fig. 1 Protein intake (g/day) distribution per time category (meal) for individual participants $(n=722)$ in the Newcastle $85+$ Study. The vertical-dashed lines represent the suggested protein amount of either $20 \mathrm{~g} / \mathrm{meal}$ or $30 \mathrm{~g} / \mathrm{meal}$ believed to be necessary for optimal protein synthesis. The arrows represent the $\%$ of all meals by all participants that meet that threshold. 75\% $(n=542)$ of participants had a meal between $5: 30$ and $8: 29,89 \%(n=643)$ from $8: 30$ to $11: 29,99 \%$ $(n=714)$ from $11: 30$ to $14: 29,90 \%(n=646)$ from $14: 30$ to $17: 29$, $86 \%(n=623)$ from $17: 30$ to $20: 29,73 \%(n=112)$ from $20: 30$ to $23: 29$ and $16 \%(n=112)$ from $23: 30$ to $5: 29$

\section{Predictors of protein intake}

Using backward stepwise multivariate linear regression modelling with a $90 \%$ significance level, significant predictors of higher protein intake adjusted for key covariates being female $(\beta=0.087 \pm 0.026, p<0.001)$, having higher energy intake $(\mathrm{MJ} / \mathrm{day})(\beta=0.109 \pm 0.006, p<0.001)$ and higher tooth count $(\beta=0.003 \pm 0.001, p=0.047)$. Significant predictors of lower protein intake included drinking alcohol $(\beta=-0.049 \pm 0.026, p=0.067)$ and having swallowing problems $(\beta=-0.040 \pm 0.023, p=0.077)$ (Table 4).

\section{Discussion}

Lower protein intake defined by different cutoffs has been associated with loss of muscle mass and strength, increased disability count, loss of independence and mortality in several cohorts of older adults [26-29]. More than one quarter of the Newcastle $85+$ Study had low protein intakes defined as protein intake $<0.8 \mathrm{~g} / \mathrm{kg}$ aBW/day. Higher contribution of MMP to total protein intake reduced the risk of low protein intake, while higher percent contribution of $\mathrm{CCP}$ and nonalcoholic beverages was associated with increased ORs of having low protein intake. Those who consumed more of their total protein intake during the morning eating occasions were more likely to be in the low than in the adequate total protein intake group ( $\geq 0.8 \mathrm{~g} / \mathrm{kg} \mathrm{aBW} /$ day). Being a woman, having higher energy intake and higher tooth count was associated with adequate protein intake in adjusted models.

We expressed protein intake per adjusted body weight to estimate the prevalence of low protein intake $(<0.8 \mathrm{~g} /$ $\mathrm{kg} \mathrm{aBW}$ ) as used in the National Health and Nutrition Examination Survey (NHANES) 2005-2006 of over 1700 participants aged 51 and over [20]. The use of actual or adjusted body weight (adjusted to reflect a healthy BMI range of 22-27 associated with favourable health outcomes in those $\geq 71$ years) affected the estimate for the prevalence of protein inadequacy by $1 \%(n=10)$ and mostly in women. Although the debate about the best way to calculate the protein requirements and the prevalence of low protein intake in older adults is still ongoing, using adjusted body weight may be more sensible to detect the population at risk. In this study the median protein intake was 61.3 (IQR 48.9-75.7) g/day (15.7\% of energy intake) [21] equivalent to $0.97(0.77-1.20) \mathrm{g} / \mathrm{kg} \mathrm{aBW} /$ day and $28 \%$ of the participants had protein intakes below $0.8 \mathrm{~g} / \mathrm{kg}$ aBW/day. Mean/median protein intakes of European older adults $\geq 80$ years range from 60.9 to $89.7 \mathrm{~g} /$ day [30] or $0.94-1.38 \mathrm{~g} /$ unadjusted $\mathrm{kg}$
Table 3 Percent contribution of each eating occasion to protein intake by low or adequate protein intake

\begin{tabular}{lllcl}
\hline Time (hh:mm) & All & Low protein $^{\mathrm{a}}$ & Adequate protein $^{\mathrm{a}}$ & $p^{*}$ \\
\hline $5: 30-8: 29$ & $11.0(5.4-17.3)$ & $13.2(5.9-20.7)$ & $10.2(5.3-16.5)$ & 0.002 \\
$8: 30-11: 29$ & $10.5(3.6-17.3)$ & $12.9(4.4-19.6)$ & $9.3(3.6-16.5)$ & 0.004 \\
$11: 30-14: 29$ & $34.6(22.4-47.9)$ & $35.0(23.2-45.9)$ & $34.3(22.3-48.6)$ & 0.566 \\
$14: 30-17: 29$ & $17.1(4.9-32.0)$ & $16.9(6.5-30.3)$ & $17.3(3.9-32.2)$ & 0.832 \\
$17: 30-20: 29$ & $20.8(8.1-38.5)$ & $19.9(8.4-36.4)$ & $21.9(7.8-39.2)$ & 0.504 \\
$20: 30-23: 29$ & $4.4(1.3-9.4)$ & $4.3(1.2-10.2)$ & $4.5(1.4-9.3)$ & 0.738 \\
$23: 30-5: 29$ & $0.0(0.0-2.2)$ & $0.0(0.0-2.2)$ & $0.0(0.0-1.6)$ & 0.415 \\
\hline
\end{tabular}

Values are medians and interquartile ranges

$a B W$ adjusted body weight $(\mathrm{kg}), h h$ hours, $m m$ minutes

*Mann-Whitney $U$ test for no difference between low $(<0.8 \mathrm{~g} / \mathrm{kg}$ aBW/day) and adequate protein intake ( $\geq 0.8 \mathrm{~g} / \mathrm{kg} \mathrm{aBW} /$ day) categories

${ }^{\mathrm{a} B o d y}$ weight was adjusted to reflect a healthy body mass index in older adults of $22-27 \mathrm{~kg} / \mathrm{m}^{2}$ 
Table 4 Factors associated with protein intake per adjusted body weight $(\mathrm{g} / \mathrm{kg}$ aBW/day)

\begin{tabular}{llllr}
\hline & Non-standardised $\beta$ & SE & $95 \%$ CI & $p$ \\
\hline All (adjusted $\left.R^{2}=0.443\right)$ & & & & \\
Constant & 0.208 & 0.056 & $0.098,0.319$ & $<0.001$ \\
Sex (men) & (Ref.) & & & \\
(Women) & 0.087 & 0.026 & $0.036,0.138$ & 0.001 \\
Energy intake (MJ/day) & 0.109 & 0.006 & $0.098,0.121$ & $<0.001$ \\
Alcohol drinker (no) & (Ref.) & & & \\
(Yes) & -0.049 & 0.026 & $-0.101,0.003$ & 0.067 \\
Tooth count & 0.003 & 0.001 & $0.00,0.005$ & 0.047 \\
Swallowing problems (no) & $($ Ref.) & & & 0.077 \\
(Yes) & -0.040 & 0.023 & $-0.085,0.004$ & \\
Women (adjusted $\left.R^{2}=0.437\right)$ & & & & 0.001 \\
Constant & 0.187 & 0.057 & $0.075,0.298$ & 0.001 \\
Energy intake (MJ/day) & 0.119 & 0.009 & $0.102,0.136$ & 0.007 \\
Tooth count & 0.005 & 0.002 & $0.001,0.008$ & $<0.001$ \\
Men (adjusted $\left.R^{2}=0.425\right)$ & & & & $<0.001$ \\
Constant & 0.302 & 0.076 & $0.168,0.468$ & 0.080 \\
Energy intake (MJ/day) & 0.104 & 0.008 & $0.088,0.120$ & \\
Alcohol drinker (no) & (Ref.) & & & $-0.185,0.010$ \\
(Yes) & -0.087 & 0.050 & & \\
\hline
\end{tabular}

Sex, disease count, years of full-time education, past occupation (NS-SEC), living alone, energy and alcohol intake, smoking, physical activity, self-rated health, diet change, Geriatric Depression Scale, standardized mini-mental state examination, disease count, number of medications, renal impairment, tooth count, swallowing problems, meal provision, luncheon club attendance, ability to go shopping and cook a hot meal were entered into the backward stepwise multivariate linear regression. Swallowing problems included dry mouth and difficulty swallowing for other reasons

$C I$ confidence interval, $S E$ standard error
BW/day (assuming a mean body weight of $65 \mathrm{~kg}$ ), which is above the current RDA [31].

Protein intake at the current RDA of $0.8 \mathrm{~g} / \mathrm{kg} \mathrm{BW} /$ day may maintain positive nitrogen balance for a short period only and lead to loss of muscle mass over time in older adults [4]. Others suggested that older adults had protein needs greater than the current RDA [10, 11, 32]. The PROTAGE study group and later the European Society for Clinical Nutrition and Metabolism (ESPEN) expert group recommended that the protein RDA for older adults should be increased to $1-1.2 \mathrm{~g} / \mathrm{kg} /$ day $[10,11]$. The Nordic Nutrition Recommendations suggested an even higher protein RDA of $1.2-1.4 \mathrm{~g} / \mathrm{kg}$ BW/day [33].

MMP was the biggest contributor to total protein intake, followed by $\mathrm{CCP}$, fish and fish dishes, and milk and milk products [34], similar to the top protein intake contributors in older adults ( $\geq 65$ years) of the NDNS rolling programme years 5-6 [35]. Participants where MMP contributed more to their protein intakes were less likely to be in the low protein intake group after adjustment for sex, energy intake, BMI and other top food protein contributors (CCP, milk and milk products, non-alcoholic beverages). CCP were also ubiquitously consumed in the Newcastle 85+ Study (data not shown) and assume a more important role as a contributor to protein intake than in younger populations. Therefore, dietary interventions to increase protein intake in the very old focusing on CCP would be promising. Those with more skewed protein distribution had higher protein intake in unadjusted models. However, additional adjustment for percent contribution of MMP to protein intake reduced the association to nonsignificant, suggesting that considerable intakes of MMP during one or two meals were the reason why skewness was higher in those with better total protein intake. An intake of $>20 \mathrm{~g}$ per meal occasion has been suggested as necessary to stimulate muscle protein synthesis in older adults [25], although the results from intervention studies investigating the benefits of even versus skewed/pulse protein intake for muscle synthesis have been mixed [36-38]. The Quebec Longitudinal Study on Nutrition and Ageing (NuAge) study, which included more than 700 older adults aged 67-84 years, found that participants with more even protein distribution throughout the day had higher lean mass and appendicular lean mass than those with a more skewed protein distribution during the 2-year follow-up [37]. However, a randomized controlled trial of 66 malnourished or at-risk hospitalised older adults ( $>70$ years) found that those who had a skewed protein intake (72\% of 
total protein intake was consumed in a single meal) gained significantly more lean mass over 6 weeks compared to those that had a more even distribution of protein intake in four meals across the day [38].

In this study, morning meals contributed more to total protein intake in the low than in the adequate protein intake group (but not more than e.g. "lunch" eating occasions). This is in agreement with others [39] which postulated that a higher contribution of morning meals to protein intake might produce greater satiety than later in the day. In fact, this observation does not seem limited to protein intake as this has also been observed with carbohydrate and fat [39].

In the present study, being a woman, having higher energy intake and higher tooth count was associated with higher protein intake (adjusted models). A recent systematic review examining the determinants of malnutrition (different outcomes used such as involuntary weight loss, low weight, low energy intake and/or appetite loss) in communitydwelling older adults ( $\geq 60$ years) identified more than 100 potential-associated factors [40]. From these, poor appetite, diabetes diagnosis, edentulousness, more recent hospitalisation and poor self-reported health were associated with low protein-energy intake [40]. Different outcomes, different model adjustments, age of participants, and, above all, the multifactorial nature of malnutrition might explain the discrepancies between the findings.

The strengths and uniqueness of the Newcastle 85+ Study lie with the large number of very old included (sociodemographically representative of the UK [13]), the multidimensional health data collected and the assessment of dietary intake using a validated approach [17, 21, 41]. Assessing dietary intake in the very old poses challenges (described in detail by Adamson et al. [17]), and potential misreporting is one of them (estimated to be $26 \%$ in the Newcastle $85+$ Study [21] with $22 \%$ underreporting). However, because protein-rich foods are less commonly underreported (unlike snacks and sweets) [42] and the 24 h-MPRs included several prompts, it is unlikely that protein intakes were underestimated. For fish, there may be a slight possibility of underreporting because the fish consumption in the UK is traditionally higher on Fridays [43], and the two 24 h-MPRs were not conducted during the weekend, (therefore, Fridays and Saturdays were not included) [41]. Weight and appetite loss are very important predictors of reduced food intake and malnutrition [40, 44]. Inclusion of these questions in our multidimensional health assessment would be invaluable to this study and strengthen our conclusions. Participants were weighed at subsequent follow-up phases. Fourteen percent $(n=76)$ of our sample had $\geq 5 \%$ of weight loss from baseline to phase 2 (after 18 months) and $40 \%(n=159)$ had $\geq 5 \%$ of weight loss from baseline to phase 3 (after 36 months). However, as with any prospective observational study of the very old, the attrition rates were high. Therefore, analyses could not be stratified for weight-loss alone or in combination with low protein intake $(<0.8 \mathrm{~g} / \mathrm{kg}$ aBW/day) due to low numbers in each category (e.g. low protein intake and weight loss). Another limitation in relation to protein intake from the 15 food groups used is that these were not disaggregated, and therefore, not only included single items (e.g. beef steak) but also composite dishes (e.g. shepherd's pie, minced beef with potato topping).

\section{Conclusion}

This study provides evidence that low protein intake is prevalent in the very old. In addition, we provide information on protein intake patterns and food group contributors to protein intake which could be helpful when considering interventions to improve protein intake in this fast-growing population group.

Acknowledgements We acknowledge the operational support of the North of England Commissioning Support Unit (formerly NHS North of Tyne) and of the local general practitioners and their staff. We also thank the research nurses, dietary coders, management and clerical team for outstanding work throughout, as well as many colleagues for their expert advice. Thanks are due especially to the study participants and, where appropriate, their families and carers. The Newcastle $85+$ Study has been funded by the Medical Research Council, Biotechnology and Biological Sciences Research Council and the Dunhill Medical Trust. The research was also supported by the National Institute for Health Research (NIHR) Newcastle Biomedical Research Centre, based at Newcastle upon Tyne Hospitals NHS Foundation Trust and Newcastle University. Funding for this research is provided by the European Horizon 2020 PROMISS Project 'Prevention Of Malnutrition In Senior Subjects in the EU', Grant agreement no. 678732. The content only reflects the author's view and the Commission is not responsible for any use that may be made of the information it contains.

\section{Compliance with ethical standards}

Ethical standards This study was conducted according to the guidelines laid down by the 1964 Declaration of Helsinki and all procedures involving human subjects were approved by the Newcastle and North Tyneside local research ethics committee (06/Q0905/2). Written informed consent was obtained from all participants, and when unable to do so, consent was obtained from a carer or a relative according to the UK Mental Capacity Act 2005.

Conflict of interest On behalf of all authors, the corresponding author states that there is no conflict of interest.

Open Access This article is distributed under the terms of the Creative Commons Attribution 4.0 International License (http://creativecommons.org/licenses/by/4.0/), which permits unrestricted use, distribution, and reproduction in any medium, provided you give appropriate credit to the original author(s) and the source, provide a link to the Creative Commons license, and indicate if changes were made. 


\section{References}

1. Elia M, Stratton RJ (2005) Geographical inequalities in nutrient status and risk of malnutrition among English people aged 65 y and older. Nutrition 21(11-12):1100-1106. doi:10.1016/j. nut.2005.03.005

2. Schilp J, Kruizenga HM, Wijnhoven HA, Leistra E, Evers AM, van Binsbergen JJ, Deeg DJ, Visser M (2012) High prevalence of undernutrition in Dutch community-dwelling older individuals. Nutrition 28(11-12):1151-1156. doi:10.1016/j.nut.2012.02.016

3. Johansson Y, Bachrach-Lindstrom M, Carstensen J, Ek AC (2009) Malnutrition in a home-living older population: prevalence, incidence and risk factors. A prospective study. J Clin Nurs 18(9):1354-1364. doi:10.1111/j.1365-2702.2008.02552.x

4. Volpi E, Campbell WW, Dwyer JT, Johnson MA, Jensen GL, Morley JE, Wolfe RR (2013) Is the optimal level of protein intake for older adults greater than the recommended dietary allowance? J Gerontol A Biol Sci Med Sci 68(6):677-681. doi:10.1093/gerona/gls229

5. Tieland M, Borgonjen-Van den Berg KJ, van Loon LJ, de Groot LC (2012) Dietary protein intake in community-dwelling, frail, and institutionalized elderly people: scope for improvement. Eur J Nutr 51(2):173-179. doi:10.1007/s00394-011-0203-6

6. Fulgoni VL 3rd (2008) Current protein intake in America: analysis of the National Health and Nutrition Examination Survey, 2003-2004. Am J Clin Nutr 87(5):1554s-1557s

7. Shakersain B, Santoni G, Faxen-Irving G, Rizzuto D, Fratiglioni L, Xu W (2016) Nutritional status and survival among old adults: an 11-year population-based longitudinal study. Eur J Clin Nutr 70(3):320-325. doi:10.1038/ejen.2015.109

8. Abizanda P, Sinclair A, Barcons N, Lizán L, Rodríguez-Mañas L (2016) Costs of malnutrition in institutionalized and community-dwelling older adults: a systematic review. J Am Med Dir Assoc 17(1):17-23. doi:10.1016/j.jamda.2015.07.005

9. Sparre-Sørensen M, Kristensen G (2015) Alzheimer's disease in the Danish malnutrition period 1999-2007. J Alzheimer's Dis JAD 48(4):979-985. doi:10.3233/jad-150472

10. Bauer J, Biolo G, Cederholm T, Cesari M, Cruz-Jentoft AJ, Morley JE, Phillips S, Sieber C, Stehle P, Teta D, Visvanathan R, Volpi E, Boirie Y (2013) Evidence-based recommendations for optimal dietary protein intake in older people: a position paper from the PROT-AGE Study Group. J Am Med Dir Assoc 14(8):542-559. doi:10.1016/j.jamda.2013.05.021

11. Deutz NE, Bauer JM, Barazzoni R, Biolo G, Boirie Y, BosyWestphal A, Cederholm T, Cruz-Jentoft A, Krznaric Z, Nair KS, Singer P, Teta D, Tipton K, Calder PC (2014) Protein intake and exercise for optimal muscle function with aging: recommendations from the ESPEN Expert Group. Clin Nutr 33(6):929-936. doi:10.1016/j.clnu.2014.04.007

12. Deer RR, Volpi E (2015) Protein intake and muscle function in older adults. Curr Opin Clin Nutr Metab Care 18(3):248-253. doi: $10.1097 / \mathrm{mco} .0000000000000162$

13. Collerton J, Davies K, Jagger C, Kingston A, Bond J, Eccles MP, Robinson LA, Martin-Ruiz C, von Zglinicki T, James OF, Kirkwood TB (2009) Health and disease in 85 year olds: baseline findings from the Newcastle $85+$ cohort study. BMJ 339:b4904. doi:10.1136/bmj.b4904

14. Collerton J, Barrass K, Bond J, Eccles M, Jagger C, James O, Martin-Ruiz C, Robinson L, von Zglinicki T, Kirkwood T (2007) The Newcastle 85+ study: biological, clinical and psychosocial factors associated with healthy ageing: study protocol. BMC Geriatr 7:14. doi:10.1186/1471-2318-7-14

15. Davies K, Kingston A, Robinson L, Hughes J, Hunt JM, Barker SAH, Edwards J, Collerton J, Jagger C, Kirkwood TBL (2014) Improving retention of very old participants in longitudinal research: experiences from the Newcastle $85+$ study. PLoS One 9(10):e108370. doi:10.1371/journal.pone.0108370

16. Nelson M, Atkinson M, Meyer J (1997) A photographic atlas of food portion sizes. Ministry of Agriculture, Fisheries and Farming (MAFF) Publications, London

17. Adamson AJ, Collerton J, Davies K, Foster E, Jagger C, Stamp E, Mathers JC, Kirkwood T (2009) Nutrition in advanced age: dietary assessment in the Newcastle 85+ study. Eur J Clin Nutr 63(Suppl 1):S6-18. doi:10.1038/ejen.2008.60

18. Food Standards Agency (2002) McCance and Widdowson's the composition of foods, sixth summary edition. Royal Society of Chemistry, Cambridge

19. Chau D, Cho LM, Jani P, St Jeor ST (2008) Individualizing recommendations for weight management in the elderly. Curr Opin Clin Nutr Metab Care 11(1):27-31. doi:10.1097/ MCO.0b013e3282f31744

20. Berner LA, Becker G, Wise M, Doi J (2013) Characterization of dietary protein among older adults in the United States: amount, animal sources, and meal patterns. J Acad Nutr Diet 113(6):809815. doi:10.1016/j.jand.2013.01.014

21. Mendonça N, Hill TR, Granic A, Mathers JC, Wrieden W, Siervo M, Seal C, Jagger C, Adamson AJ (2016) Macronutrient intake and food sources in the very old: analysis of the Newcastle 85+ study. Br J Nutr 115(12):2170-2180. doi:10.1017/ S0007114516001379

22. Chandola T, Jenkinson C (2000) The new UK National Statistics Socio-Economic Classification (NS-SEC); investigating social class differences in self-reported health status. J Public Health Med 22(2): 182-190

23. Innerd P, Catt M, Collerton J, Davies K, Trenell M, Kirkwood TBL, Jagger C (2015) A comparison of subjective and objective measures of physical activity from the Newcastle 85+ study. Age Ageing 44(4):691-694. doi:10.1093/ageing/afv062

24. Kingston A, Davies K, Collerton J, Robinson L, Duncan R, Kirkwood TB, Jagger C (2015) The enduring effect of education-socioeconomic differences in disability trajectories from age 85 years in the Newcastle 85+ study. Arch Gerontol Geriatr 60(3):405411. doi:10.1016/j.archger.2015.02.006

25. Paddon-Jones D, Rasmussen BB (2009) Dietary protein recommendations and the prevention of sarcopenia: protein, amino acid metabolism and therapy. Curr Opin Clin Nutr Metab Care 12(1):86-90. doi:10.1097/MCO.0b013e32831cef8b

26. Visser M, Kritchevsky SB, Goodpaster BH, Newman AB, Nevitt M, Stamm E, Harris TB (2002) Leg muscle mass and composition in relation to lower extremity performance in men and women aged 70 to 79: the health, aging and body composition study. J Am Geriatr Soc 50(5):897-904

27. Sahni S, Mangano KM, Hannan MT, Kiel DP, McLean RR (2015) Higher protein intake is associated with higher lean mass and quadriceps muscle strength in adult men and women. J Nutr 145(7):1569-1575. doi:10.3945/jn.114.204925

28. Houston DK, Nicklas BJ, Ding J, Harris TB, Tylavsky FA, Newman AB, Lee JS, Sahyoun NR, Visser M, Kritchevsky SB (2008) Dietary protein intake is associated with lean mass change in older, community-dwelling adults: the Health, Aging, and Body Composition (Health ABC) Study. Am J Clin Nutr 87(1):150-155

29. Meng X, Zhu K, Devine A, Kerr DA, Binns CW, Prince RL (2009) A 5-year cohort study of the effects of high protein intake on lean mass and BMC in elderly postmenopausal women. J Bone Miner Res 24(11):1827-1834. doi:10.1359/jbmr.090513

30. Hill TR, Mendonça N, Granic A, Siervo M, Jagger C, Seal CJ, Kerse N, Wham C, Adamson AJ, Mathers JC (2016) What do we know about the nutritional status of the very old? Insights from three cohorts of advanced age from the UK and New Zealand. Proc Nutr Soc 75(3):420-430. doi:10.1017/S0029665116000203 
31. Department of Health: Committee on Medical Aspects of Food Policy (COMA) (1991) Report on health and social subjects 41: dietary reference values for food energy and nutrients for the United Kingdom. The Stationery Office, London

32. Cuthbertson D, Smith K, Babraj J, Leese G, Waddell T, Atherton P, Wackerhage H, Taylor PM, Rennie MJ (2005) Anabolic signaling deficits underlie amino acid resistance of wasting, aging muscle. FASEB J 19(3):422-424. doi:10.1096/fj.04-2640fje

33. Pedersen AN, Cederholm T (2014) Health effects of protein intake in healthy elderly populations: a systematic literature review. Food Nutr Res. doi:10.3402/fnr.v58.23364

34. Mendonça N, Mathers JC, Adamson AJ, Martin-Ruiz C, Seal CJ, Jagger C, Hill TR (2016) Intakes of folate and vitamin B12 and biomarkers of status in the very old: the Newcastle $85+$ study. Nutrients 8(10):604. doi:10.3390/nu8100604

35. Bates BCL, Nicholson S, Page P, Prentice A, Steer T, Swan G, (2016) National Diet and Nutrition Survey: results from years 5 and 6 (combined) of the rolling programme (2012/13-2013/14): appendices and tables. Department of Health and Food Standards Agency. https://www.Gov.Uk/government/statistics/ndns-resultsfrom-years-5-and-6-combined. Accessed 21 Feb 2017

36. Mamerow MM, Mettler JA, English KL, Casperson SL, Arentson-Lantz E, Sheffield-Moore M, Layman DK, Paddon-Jones D (2014) Dietary protein distribution positively influences 24-h muscle protein synthesis in healthy adults. J Nutr 144(6):876-880. doi:10.3945/jn.113.185280

37. Farsijani S, Morais JA, Payette H, Gaudreau P, Shatenstein B, Gray-Donald K, Chevalier S (2016) Relation between mealtime distribution of protein intake and lean mass loss in free-living older adults of the NuAge study. Am J Clin Nutr 104(3):694-703. doi:10.3945/ajen.116.130716

38. Bouillanne O, Curis E, Hamon-Vilcot B, Nicolis I, Chretien P, Schauer N, Vincent JP, Cynober L, Aussel C (2013) Impact of protein pulse feeding on lean mass in malnourished and at-risk hospitalized elderly patients: a randomized controlled trial. Clin Nutr 32(2):186-192. doi:10.1016/j.clnu.2012.08.015

39. de Castro JM (2009) When, how much and what foods are eaten are related to total daily food intake. Br J Nutr 102(8):1228-1237. doi:10.1017/s0007114509371640

40. van der Pols-Vijlbrief R, Wijnhoven HAH, Schaap LA, Terwee CB, Visser M (2014) Determinants of protein-energy malnutrition in community-dwelling older adults: a systematic review of observational studies. Ageing Res Rev 18:112-131. doi:10.1016/j. arr.2014.09.001

41. Mendonça N, Hill TR, Granic A, Mathers JC, Wrieden W, Siervo M, Seal C, Jagger C, Adamson AJ (2016) Micronutrient intake and food sources in the very old: analysis of the Newcastle 85+ study. Br J Nutr 116(4):751-761. doi:10.1017/S0007114516002567

42. Macdiarmid J, Blundell J (1998) Assessing dietary intake: who, what and why of under-reporting. Nutr Res Rev 11(2):231-253. doi:10.1079/nrr19980017

43. Welch AA, Lund E, Amiano P, Dorronsoro M, Brustad M, Kumle M, Rodriguez M, Lasheras C, Janzon L, Jansson J, Luben R, Spencer EA, Overvad K, Tjønneland A, Clavel-Chapelon F, Linseisen J, Klipstein-Grobusch K, Benetou V, Zavitsanos X, Tumino R, Galasso R, Bueno-de-Mesquita HB, Ocké MC, Charrondière UR, Slimani N (2002) Variability of fish consumption within the 10 European countries participating in the European Investigation into Cancer and Nutrition (EPIC) study. Public Health Nutr 5(6b):1273-1285. doi:10.1079/PHN2002404

44. Kruizenga HM, Seidell JC, de Vet HC, Wierdsma NJ, van Bokhorst-de van der Schueren MA (2005) Development and validation of a hospital screening tool for malnutrition: the short nutritional assessment questionnaire (SNAQ). Clin Nutr 24(1):75-82. doi:10.1016/j.clnu.2004.07.015 